\title{
Between Haskalah and Zionism. The Example of the Jewish Community of Brody
}

\author{
Dominika Rank \\ (Ukrainian Catholic University) \\ e-mail: dominika.rank@gmail.com
}

Key words: Brody, Haskalah, Zionism, Galicia, $19^{\text {th }}$ century

\begin{abstract}
In Galicia the propagation of Jewish diaspora nationalism in the early phase of this movement was welcomed by liberal Jewish organizations as just another step towards the ideals of Enlightenment. However, while Zionism gradually emerged as a separate political movement in Galicia, in Brody remained just a part of the cultural Enlightenment process of the Haskalah. In Lviv and other Galician towns, the same period was characterized by the intense development of Polish, Ukrainian and Jewish national ideologies - a markedly different situation compared to the pro-Austrian, centrist Brody, with its established Jewish economic elite with Austrian liberal supra-national identity. Owing to the dominant role of Jews in the economic, cultural and to some degree political life of the city, the local population did not encounter significant levels of antiSemitism. This absence of a group that would symbolize the "alien, hostile other"- the absence of anti-Semitism - meant that the Zionism could not establish itself as a saviour and defender of the Jews in $19^{\text {th }}$ century Brody. As such, Zionism was not regarded as a serious alternative to the Austrian liberal ideology espoused by the local population.

The situation was changed with the establishment of universal suffrage in the Austrian Empire and the accompanying development of mass election campaigns contributed to the population's politicization and the formation of a national identity in both Brody and throughout Galicia. Together with the use of modern political campaign methods and the activities of some members of the Jewish community, Zionism in Brody began to attract more active and conscious supporters.
\end{abstract}

"The Metropolis of Jewish towns", "a Galician Jerusalem"- though now merely a small provincial town in Ukraine, Brody has retained its previous glory in the collective memory of the Ashkenazi Jewry, thanks to its renown for Orthodox education (kloyz) and as a once flourishing center of Haskalah. ${ }^{1}$ At the end of $18^{\text {th }}$ century Brody was one of the largest and most influential cities of Ashkenazi Jewry. ${ }^{2}$ It was unusu-

${ }^{1}$ Descriptions of Brody as the "Metropolis of Jewish towns" were often used in the Jewish newspaper Ivri anokhi/Ha-Ivri (1865-1899). The term "Galician Jerusalem" has a more folkloric origin, but Austrian Emperor Franz II made one of the most famous comparisons of Brody with Jerusalem in 1774 during his visit to the city. The Emperor was so impressed by the quantity of Jews in Brody and by the warm and rich welcome organized by this community headed by Rabbi Leib Bernstein, that he remarked "Now I understand why I have the title Emperor of Jerusalem" (Emperor of Jerusalem was one of titles given to Austrian emperors). Honigsman 2011: 31 .

2 The Kloyz of Brody (Klaus rabata d'kegila k'dosza) was one of the reasons for Brody's fame as a Jewish educational center in Eastern Europe. It was built by Haim Landau in 1742. Wurm 1935: 91. 
ally homogenous - the percentage of Jews residing in Brody peaked at $88 \%$ and until World War I never dropped below 70\%. ${ }^{3}$ This composition made Brody quite exceptional among other Galician cities. ${ }^{4}$ In 1764, the town's Jewish community was one of the biggest in the Polish Rzeczpospolita (Commonwealth), numbering 8,600 people out of a total population of about 10,000, and greater than in Krakow, where 4,150 Jews lived and which also had a total populace of 10,000 in $1791 .^{5}$ In this context, the history of Jews of Brody more closely resembles the history of a dominant majority and not that of a minority, as it is usually presented in the historiography of the Jewish Diaspora. This dominance was true not only in quantitative terms: the wealth and influence of the Jewish economic elite, as well as its support of Haskalah and maskilim, shaped the town's cultural and political life for almost one hundred years. The conventional beginning of these tendencies was the incorporation of Brody into the Austrian Empire in 1772 and the simultaneous advent of modernization — partly voluntary, partly forced — of the local population of the region.

The quantitative and qualitative advantage of the Jewish population in Brody in the $19^{\text {th }}$ and early $20^{\text {th }}$ centuries was also the reason why it did not experience violent antiSemitism. Without a doubt, anti-Semitism played a crucial role in the emergence of Zionism. However, the example of Brody happens to be an interesting historical anomaly, since a Jewish national movement arose in the town practically without the influence of anti-Semitism.

From the 1870 s, Brody increasingly began to lose its influence due to a variety of political and economic factors, causing a large part of the local economic elite to leave the town and emigrate, most of them to Vienna. ${ }^{6}$

But even economic decline and the emigration of its inhabitants, and in particular the economic elite, does not fully explain why Brody - which still had one of the largest Jewish communities in Galicia-did not have such a significant role in the development of the Zionist movement as it was earlier the case with the Haskalah. Certainly, the names of two Zionists from Brody are well known today-Nathan Michael Gelber and Dov Sadan - but even here some clarifications are necessary. Dov Sadan was born in 1902, meaning that he only became an active member of the Zionist movement when the Zionist movement in Galicia was gradually rejecting the ideas of promoting cultural, political and economic rights of the Jewish Diaspora. Instead, Zionism turned its attention to the creation of Israel as an independent state. Therefore, Dov Sadan represented a newer generation in the Zionist movement, one which was better adapted to the changing social and political context. On the other hand, Nathan Michael Gelber, born in 1891, turns out to be a more informative example of the complexity of the Jewish national

3 This numbers relate to the period from 1778-1910, when the population ranged from 10,887 to 18,055 . Kuzmany 2011: 345.

${ }^{4}$ For example, the percentage of Jews in Lviv did not exceed 30-33\%. Melamed 1994: 237. The percentage of Jews in smaller Galician towns was higher than in Lviv, for example in 1910 in Buchach it reached $63 \%$, while in Kolomyia- $50 \%$, but compared to Brody these towns had a less significant cultural and economic impact than Brody at the time. Weinfeld 1912: 30-32.

5 Mahler 2006: 23.

6 Among the wealthy families that left Brody and migrated to Vienna was that of Amalia Nathanson, the future mother of Sigmund Freud. Another example of those who left was Adele von Mises (Landau), the mother of Ludwig von Mises, one of the theorists of the liberal economic system. Jörg 2007: 8. 
movement's development in the Galician context, and in particular in Brody. During his time in Brody (where he studied at and graduated from the gymnasium named after Crown Prince Rudolf of Austro-Hungary), Gelber was a proponent of what Joshua Shanes has termed 'Jewish diaspora nationalism'. ${ }^{7}$ This form of Zionism placed more emphasis on the needs and questions of Jewish communities in Europe than on the creation of an independent Israel.

One of the particularities of this type of Zionism in Galicia was its support for the Austrian government and, specifically, for the Austrian monarch. The private archive of Nathan Michael Gelber contains the draft of a speech he gave in 1916. The speech was dedicated to the celebration of Franz-Joseph I's name day:

There are many victims in our town from the events of 14 August 1914: we can still see traces of the damage to our synagogue, many people have left this place. And still, we are staying here today and we are happy that we can celebrate this outstanding holiday! We are under the protection of the regiment of Franz-Joseph and his army even during the time of the enemy's offense.

Due to Franz-Joseph, we Jews can enjoy our freedom during our time in this world. Our sons will transmit our gratefulness for our freedom...

Thanks to him, everyone in our town is free and equal, there is no longer any caste that could oppress us! The military and officials act with us and not against us.

However, still today there is no lack of voices among our opponents who argue that Jews are just fighting for their rights and do not care about filling the hand which gives them everything. Our answer (to this insult) will be the heroism of our brothers in the fight against our enemy... . ${ }^{8}$

The Austrian patriotism of the Jewish Zionist Nathan Michael Gelber was not limited to appeals and proclamations; he also fought on the front together with hundreds of other Jewish volunteers. ${ }^{9}$

Both Nathan Michael Gelber and Dov Sadan are the results of the complex development of the Zionist movement in Brody and across Galicia. Theirs biographies and theirs achievements are well known, and it is precisely this fact that could influence all conclusions about the process of the formation of the Jewish national movement in the town.

In the beginning of $20^{\text {th }}$ century, the Galician Zionist press did not try to hide its general disappointment and worries about the very passive attitude of one of Galicia's largest Jewish communities towards Zionism. Even small Galician shtetels outperformed Brody in their Zionist activities. ${ }^{10}$ Before going deeper into an analysis of the specifics of Zionism in Brody itself, it is worth briefly returning to the idea of Haskalah and to the reasons why it thrived and gained acceptance in the city.

Brody began its history as a trade center with a large and influential class of Jewish merchants and bankers. Brody's economic community arose in the $17^{\text {th }}$ century and

7 Shanes 2012: 53.

8 "Brody", Die Beschreibung der Feierlichkeiten des 1916 Namenstages des Kaisers in Brody am 4.10.1916 durch die Juden (Manuskript), P83/H42, from the private archive of Nathan Michael Gelber in The Central Archives for the History of the Jewish People Jerusalem [translated from the German original by D.R.].

${ }^{9}$ Rozenblit 2001: 39-58.

${ }_{10}$ Wschód, a Zionist newspaper in Polish, published many articles about the development of Zionism in Brody. See, for example, Wschód, 1905, no. 6: 5. 
steadily grew, especially after Emperor Joseph II granted Brody the status of a free trade city. Brody had strong trade ties with numerous major European commercial centers like Leipzig, Frankfurt, Gdansk, Amsterdam and others. These links were not purely economic but were also cultural. Merchants were more active supporters of Haskalah ideas than those working in education. The local economic elite had sufficient financial strength to maintain and protect their maskils from the more conservative and Orthodox part of the Jewish population. ${ }^{11}$

Due to their trade relations with different countries, Brody's merchants were among the first to understand the need for change in traditional (Orthodox) Jewish society. In particular, a secular education and learning a foreign language were major ingredients of economic success. Above all, this applies to the education that these merchants gave their children. In the $19^{\text {th }}$ century, the education given to merchants' children went far beyond traditional religious education, with foreign languages and geography becoming an integral part of the curriculum. Mayer and Moses, the sons of Alexander Kallir, one of the richest and most powerful bankers in the town, received such an education. ${ }^{12}$ They later became members of the economic elite, just like their father. They also promoted their more progressive educational views among the rest of Brody's Jewish population, providing financial support to different educational institutions and funds. Their efforts were even noticed in Vienna. ${ }^{13}$ In 1859 , Mayer Kallir was the first Jew from Galicia to receive the title of nobility from Franz-Joseph I as a present on his golden wedding anniversary. ${ }^{14}$

Due to the economic elite's support and its economic importance, from the early $19^{\text {th }}$ century, Brody became one of the major centers of Haskalah. The Jewish Enlightenment spread in Galicia at the beginning of the $19^{\text {th }}$ century and flourished in Brody in the 1820s and 1830s. Israel of Zamosc, who resided in Brody between 1752 and 1772, was a teacher of Moses Mendelssohn. At that time, such famous maskils as Lapin Mendel (1749-1826), Satanover Isaac Levinson (1817-1820), Jacob Samuel Byk (1770-1831), Joseph Pearl, Erter Isaac (1818-1825), and Nachman Krochmal lived in Brody. Support for the maskils' activities began to take on a practical purpose, allowing for integration into Christian society and the strengthening of ties, primarily trade relations.

Haskalah was certainly not restricted to the activities of few individuals. Maskilim formed circles to promote the cultural and educational goals of the Enlightenment. In Brody, one could find numerous examples of such societies. In the second half of the $19^{\text {th }}$ century, societies with a cultural mission to develop Hebrew were founded in Brody, such as the "Hebraeisch-literarischer Lesezirkel" and the "dorsche leschon eber" that first opened its doors in 1862 , with Isaac Wolkenstein ${ }^{15}$ acting as president. This so-

11 Brody had both a progressive rabbi, Jehiel Michel Kristianpoller, and also a more conservative rabbi, Schlomo Kluger; Margoshes 2008: 11; Landesmann 1997: 128.

12 Alexander Kallir himself was also involved in the development of the progressive educational system for Jewish boys. Over a number of years, he was a patron and inspector of the Jewish school in Brody. "Kallir" Teka Schneidera 851, National Archive in Krakow.

${ }^{13}$ Franz-Joseph I appreciated efforts of Mayer Kallir as a loyal and faithful monarchist and liberalist, trustworthy supporter of the process of modernizing Galician Jewry. For example, Kallir endowed a grant of 5,000 Austrian forint for Jews who finished school in Brody and decided to learn and pursue professions untypical for Jews or to work in agriculture. Ibid.

14 Herzberg-Fränkel 1875: 67.

15 Der Neuezeit 1867, no. 17. 
ciety was divided into two groups according to age - the senior members, including representatives of the city's economic elite - and a younger group, with a total of 41 members. The main task of the senior members of the group was to mentor and help younger members. The society arranged literary evenings during which books were read in German and Hebrew, including P. Ostiller's report "Mora Newochim" in Hebrew. Its members also translated works from German into Hebrew, such as the introduction to Kant's "Critique of Pure Reason". Perhaps 41 members can be regarded as an insignificant number in a population of 10,000. However, considering that secular Jewish intellectuals had just begun to appear, the society's relevance and influence in mid-19 $9^{\text {th }}$ century Galicia should not be underestimated.

The well-known Hebrew newspaper Ivri anokhi / Ha-'Ivri, which appeared in Brody in 1865 , had a considerably wider audience than the abovementioned group. Barukh Verber (Werber, 1810-1876) edited the first 12 volumes, while his son, Ya'akov Verber (1859-1890), edited the remaining 14. In the first issue, the editor wrote that the aim of this paper was to revive and develop Hebrew so that the language would become the language of science. ${ }^{16}$ The newspaper continued to be published, mostly in Lviv, until 1890. It reflected Haskalah views, promoted the spread of education and encouraged the fight against obscurantism in the face of Hasids and Tzadiks. Among the newspaper's correspondents was Yehoshu Heshel Schorr (Yahash, 1814-1895), one of Galicia's famous scholars of the $19^{\text {th }}$ century. He was a long-time editor and publisher of the annual He-Haluts publication, with a total of 13 volumes published between 1852 and 1889 . Like Ivri anokhi, He-Haluts also supported the ideas of the Enlightenment, with its emphasis on rationality. The journal's main goal was to adapt Judaism to the requirements of contemporary scientific methods of knowledge. Articles in the fields of biblical and rabbinistic literature, Halakhah, were published in the journal. In a series of his own articles, Schorr tried to introduce a critical analysis of the biblical text, demonstrating erudition and encyclopedic knowledge. ${ }^{17}$ As with other Jewish Haskalah organizations in eastern Galicia, the Ivri anokhi journal maintained a centrist liberal political position and was loyal to the monarchy while opposing the Polish national movement.

Those organizations demonstrated sympathy and support for the burgeoning Jewish Diaspora nationalism, which they regarded as a continuation of the Haskalah agenda. An example of this attitude can be found in the Jewish newspaper Der Israelit (Lviv) - the press organ of the liberal Jewish society Shomer Israel:

Obviously, nobody has anything against the national movement among Jews. It is important to note here what a powerful and liberating spirit comes of this-it strengthens the consciousness of its own origin and meaning of the awareness of the Jewish people's own history. ${ }^{18}$

Among academic and Zionist circles of the time there was a lack of clear boundaries between Jewish cultural and political organizations. This situation was exacerbated by the fact that the Zionists initially adhered to Vienna's centrist and liberal political

\footnotetext{
16 Ivri Anochi, 1865, no. 1.

17 Menda-Levy 2010.

18 Der Israelit 1896, no. 10: 17.
} 
position, as did proponents of Haskalah. The Galician Zionists' centrism was also one of reasons why they were subject to criticism from Polish Galician nationalists. ${ }^{19}$

In Lviv, the Mikra Kodesh Holy Assembly Society, which was established in 1883 and headed by Joseph Kobak, enjoyed the support of the Shomer Israel society. Kobak himself was a member of Hashomer Izrael, and actually continued to promote educational traditions among members of his community. According to Joseph Schanes, Mikra Kodesh was not the answer to anti-Semitism, or in other words, a Jewish nationalist organization, but was rather a continuation of Jewish Enlightenment ideas, modified to fit modern conditions. ${ }^{20}$ Shmuel Finer also believes Mikra Kodesh to be some kind of "national Haskalah". ${ }^{21}$ In its early phase, cooperation between the different associations was established. For instance, Hashomer Izrael funded the Maccabee festival, and also provided space for these celebrations. These festivals became an important area of activity for Jewish nationalists in their quest to form a national Jewish identity among their co-religionists. According to Israel, the result of this collaboration was the confusion of Jewish nationalism in its early phase with the Haskalah movement and maskils. These movements joined forces in their pro-government stance, displaying strong centrism and a common expectation of the Jewish community's emancipation across the empire, but without losing their Jewish cultural and religious identity. ${ }^{22}$

Ivri anokhi published a series of articles on the First Congress of Hovevei Zion in Katowice in 1884, which adopted the main objectives of the society, including the return to Eretz. ${ }^{23}$ For example, Ivri anokhi contains an article that does not condemn the ideas of the society but does criticize the poor organization of its members and, in particular, the decision to dispatched 11 young people to Eretz without providing them with adequate means of subsistence. ${ }^{24}$ The activities of the Hibat Tsiyon society, which actively advocated for Jews to return to the Promised Land, met with a similar reaction. Ya'akov Verber, editor of Ivri anokhi, published a letter in 1885 that described life in Palestine in negative terns while supporting the Haskalah idea of building a future for Jews in their country of residence. ${ }^{25}$

As in the rest of Galicia, several Zionist associations also appeared in Brody. As Gelber points out, the town's first pro-Zionistic society, Shivat Zion, was founded in 1887 under the leadership of Juda Leib Pilpel. This society's main aim was the restoration of Judaism by celebrating Jewish festivals and Hebrew lectures. As such, one cannot help but notice that Shivat Zion's work was identical to that carried out by the Hebraeisch-literarischer Lesezirkel society. Judging by the range of their interests, neither organization conducted any political activity. According to Gelber, in 1890, a branch of the Zion Society consisting of students of the Crown Prince Rudolf high school began its operations in Lviv. Gelber does not consider that the society's members were Jewish nationalists, but believes that the society was more of a cultural club. One issue of the Zionist newspaper

\footnotetext{
19 Jedność, Organ Żydów Polskich 1909, no. 4.

20 Shanes 2012: 53.

21 Feiner 2004: 317.

22 Bartal 1998: 19.

23 More details can be found here: Salmon 1998: 25-44.

${ }^{24}$ Ivri Anochi 1885 , no. 3.

25 Ibid.
} 
Wshód contains an article that states that although the city's first Zionist society Haibri ${ }^{26}$ opened its doors in 1899, it had just a few rather inactive members whose only achievement was in organizing Hebrew courses called "Beth Am". ${ }^{27}$ Meanwhile, it took longer to set up similar societies in Striy, Drohobych and Tarnov, that in turn were followed by the foundation of a Jewish society in Rzeszów in 1888. A similar situation concerns the Maccabee festivals organized by the Zion society in Brody that were first held in 1904. In comparison, proponents of Zionism in Stanislav first held a Maccabee festival in 1885the same year in which the society was founded. ${ }^{28}$ The first Maccabee festival in Brody was held in the Musical Society Hall and consisted of a concert of choral singing. The festival was attended not only by Jews but also by Ruthenians, the Sokił Polish society and the Zwolennicy bożego drzewka Polish Church Society. ${ }^{29}$ As the Wschód newspaper noted with regret, the Maccabee festival in Brody was not an entirely Jewish event. ${ }^{30}$ Such diversity at a Zionist function can probably be explained by the fact that the festival was still perceived as a cultural event and, therefore, was intended for the general public. In its early days, the Zion society led a relatively active programme, which included lectures titled "About the Maccabees", "The Bar Kochba Revolt," "The Spanish Inquisition" and "Yearning for Zion in the life of our nation". The Moriah newspaper notes with some regret that the majority of participants were women who most willingly engaged in reciting Perets' verses. The same newspaper also noted that Brody's literary movement was the sole expression of Zionism. ${ }^{31}$

In 1908, the Jüdische Zeitung newspaper published a favorable article focused on the establishment of the Iwria society, headed by Naftali Siegelbaum. The aim of the society was to develop knowledge of Hebrew, and although membership initially did not exceed 30 members, Iwria nevertheless boasted its own library of Hebrew publications. The society held sporadic meetings in Hebrew but did not organize any lectures or courses. Separately, one can highlight the fact that Naftali Siegelbaum's family was the only one in town where the children were fluent in Hebrew and used it to communicate, even at home. ${ }^{32}$ The society lasted less than a year and closed its doors due to a lack of members. This case further proves the point that at the beginning of the $20^{\text {th }}$ century such activity modeled after the early maskil circles of the first half of the $19^{\text {th }}$ century no longer met the needs of Jewish intellectuals and other segments of the Jewish community. Instead, various public lectures gained great popularity. Accordingly, various societies were formed that were aimed to attract large audiences. For instance, the Bet Am society founded by Zion taught the Hebrew language and was actively involved in organizing Hebrew courses. Initially there were three Hebrew classes a week, but these soon increased to six under the guidance of professional teachers from Russia. The society organized a total of eight courses of Hebrew, four of which were for women. ${ }^{33} \mathrm{In}$ 1908, yet another Jewish society was formed - Zenath - the aim of which was the moral

\footnotetext{
${ }^{26}$ Gelber was a member of this society for some time.

27 Wschód 1902, no. 105: 9.

28 Gaisbauer 1988: 63.

${ }_{29}$ Wschód 1903, no. 117: 6.

30 Ibid.

31 Moriah 1904, no. 5: 198.

32 Jüdische Zeitung 1908, no. 2: 17.

33 Moriah 1905, no. 11: 286.
} 
and physical development of Jewish youth. In its early days, the society suffered from a shortage of members. However, after developing a series of lectures on hygiene and sexual life, including on sexually-transmitted diseases, alcoholism, hygiene in the Torah, masturbation, and the physical and mental state of Jewish youth, as well as the addition of a library of 48 books, membership grew by between $15 \%$ and $25 \%$ a month. ${ }^{34}$ In addition, the Poalei Zion society, which attempted to attract merchants and their aids and artisans, was active during a short period of time, albeit with little success. ${ }^{35}$

The Zion society's athenaeum first opened its doors in 1908, and just a year later had 80 full-time members (out of 12,188 Jews in Brody; meanwhile there were 108 active readers among the 4,000 Jews in Horodets, ${ }^{36}$ and 126 out of the 3,500 Jews in Kalush) ${ }^{37}$ The society also organized lectures on the following subjects: "Das Wesen der Histerie", "Darwin's theory", "Rosenfeld, Maurice", "Electrification" and "Women in German literature", among others.

Another important indicator of the weak connections between Brody's "Zionists" and the general Jewish national movement, even in the narrow Galician context, was the reaction of this community to Theodor Herzl's death in 1904. Funeral processions were held in many cities and settlements of Galicia and reports were submitted to the Zionist newspaper Wschód [East]. In comparison to other cities, Brody stood out in its passivity to the passing of Herzl. In Brody, the only tribute was a funeral service in a synagogue, while in other cities, including Tarnow, Przemysl, Sanok, Wieliczka and Coloma, mourning processions were held, posters were hung up and a seven-day mourning period was declared. The mourning ceremonies themselves had the nature of mass demonstrations. In Zhovki, Chertkov and Rzeszow a 30-day mourning period was announced and black banners were put on display. Meanwhile, a foundation named after Theodor Herzl was established in Yaroslav, a park named after Herzl was opened in Tarnobrzeg, and a library was opened in Denbitse. ${ }^{38}$ This could be an indication that Theodor Herzl was not seen by the local Jewry in Brody as an important political figure with whom they could identify their own political and cultural views. Equally, it demonstrates that, compared to the rest of Galicia, Zionism took longer to be recognized as a political movement, and was seen instead as an extension of the ideas of Haskalah.

Against this backdrop, the victory of a Zionist candidate Adolf Stand in the 1907 elections may seem rather surprising. However, other factors contributing to Stand's victory in Brody besides the development of the Zionist movement should not be overlooked. Stand's political opponent in Brody, Kolisher, was a pro-Polish Jew who relied solely on the average urban pro-Polish bourgeoisie. Stand, on the other hand, declared loyalty to the Poles and Polish culture and mastered both Polish and Yiddish while also promising to protect the interests of artisans and traders. He also promised to represent the town's interests by boycotting the Chamber of Commerce's move to Ternopil, as had already been discussed in Lviv. In this way, Stand managed to capture the interests of virtually all segments of the population. After the introduction of a new voting system in

\footnotetext{
${ }^{34}$ Moriah 1908, no. 1-30.

35 Wschód 1905, no. 6: 5.

${ }^{36}$ Statistical data on the population of Horodenka, "Horodenka, Ukraine", Jewishgen.

37 Statistical data on the population of Kalush, "Kalush, Ukraine", Jewishgen.

38 Wschód 1904, no. 18.
} 
1905, which gave all men above age 24 the right to vote, the ability to feel and respond to mass sentiment was critical for a successful election campaign. Zionists actively used the latest technologies, including railroad and press, to disseminate information among the population more efficiently. ${ }^{39}$ In addition, a deal was struck between Stand and representatives of the Ruthenian party, according to which the Jews in Ternopil were supposed to vote for a Ukrainian candidate in exchange for Ukrainians' support for Stand in Brody. As a result Stand, became the first Zionist representative of Brody in parliament. ${ }^{40}$

\section{Conclusions}

The formation of a strong and influential Jewish economic elite in Brody in the $18^{\text {th }}$ century, together with this elite's more progressive views towards modernization and belief in the necessity of the Jewish community's integration into the political, economic and cultural body of the Empire, resulted in the city becoming one of the centres of Haskalah. This tendency remained almost until the last quarter of the $19^{\text {th }}$ century. The propagation of Jewish diaspora nationalism in the early phase of this movement was welcomed by liberal Jewish organizations as just another step towards the ideals of Enlightenment. However, while Zionism gradually emerged as a separate political movement in Galicia, in Brody remained just a part of the cultural Enlightenment process of the Haskalah. Zionist meetings in Brody had an exclusively cultural and not a political character, and were also attended by representatives of other ethnic groups, including the Catholic community. At the same time, Brody continued to be loyalty to the centrist, liberal Austrian Habsburg dynasty, a fact that caused discontent above all among Polish Galician nationalists. The enduring popularity of Haskalah, together with the political loyalty to the Empire of Brody's intellectual and economic elite in the late $18^{\text {th }}$ and early $19^{\text {th }}$ centuries, explains the town's passive resistance to political nationalism - be it Polish or Jewish - among the city's Jewish community.

In Lviv and other Galician towns, the same period was characterized by the intense development of Polish, Ukrainian and Jewish national ideologies - a markedly different situation compared to the pro-Austrian, centrist Brody, with its established Jewish economic elite. In addition, owing to the dominant role of Jews in the economic, cultural and to some degree political life of the city, the local population did not encounter significant levels of anti-Semitism. This absence of a group that would symbolize the "alien, hostile other" - the absence of anti-Semitism - meant that the Zionism could not establish itself as a saviour and defender of the Jews in $19^{\text {th }}$ century Brody. As such, Zionism was not regarded as a serious alternative to the Austrian liberal ideology espoused by the local population.

The establishment of universal suffrage in the Austrian Empire and the accompanying development of mass election campaigns contributed to the population's politicization and the formation of a national identity in both Brody and throughout Galicia. Together with the use of modern political campaign methods and the activities of some

\footnotetext{
39 Shanes 2012: 198.

40 Jedność 1907, no. 15: 6.
} 
members of the Jewish community, Zionism in Brody began to attract more active and conscious supporters. From the 1870 s onwards, the liberal system gradually lost its influence, and in the early $20^{\text {th }}$ century was already no longer regarded by the younger generations as a vector of possible further development. Rather, liberalism gave way to nationalist movements.

\section{BIBLIOGRAPHY}

\section{Jewish newspapers}

Der Israelit 1896, no. 10.

Ivri Anochi 1865, no. 1; 1885, no. 3 .

Jedność, Organ Żydów Polskich 1907, no. 15; 1909, no. 4.

Jüdische Zeitung, 2 (1908): 17.

Moriah 1904, no. 5; 1905, no. 11; 1908, no. 1-30.

Der Neuezeit 1862, no. 17.

Der Neuezeit 1867, no. 17.

Wschód 1902, no. 105.

Wschód 1903, no. 117.

Wschód 1904, no. 18.

Wschód 1905, no. 6.

\section{Primary literature}

Die Beschreibung der Feierlichkeiten des 1916 Namenstages des Kaisers in Brody am 4.10.1916 durch die Juden (Manuskript), P83/H42, from the private archive of Nathan Michael Gelber in The Central Archives for the History of the Jewish People Jerusalem.

"Kallir" Teka Schneidera 851, National Archive in Krakow.

Herzberg-Fränkel, L., Mayer von Kallir, Der Israelit, 7 (1875): 67.

Weinfeld, I. (1912), Ludność Miejska Galicji i jej Skład Wyznaniowy, 1881-1910, in: Wiadomości statystyczne o stosunkach krajowych, vol. XVI, no. 2, Lwów.

\section{Secondary literature}

Bartal, I. (1998), Responses to Modernity: Haskalah, Orthodoxy and Nationalism in Eastern Eastern Europe, in: S. Almog, J. Reinharz, A. Shapira (eds.), Zionism and Religion, Hanover-London: Brandeis University Press: 13-24.

Feiner, S. (2004), Haskala and History. The Emergence of a Modern Jewish Historical Consciousness, Oxford.

Gaisbauer, A. (1988), Davidstern und Doppeladler. Zionismus und jüdischer Nationalismus in Österreich 1882-1918, Vienna: Böhlau Verlag.

Jörg, G. (2007), Mises: The Last Knight of Liberalism, Vienna: Ludwig von Mises Institute.

Honigsman, J. (2011), Evrei goroda Brody [Jews of Brody], Lviv.

Kuzmany, B. (2011), Brody: Eine Galizische Grenzstadt Im Langen 19. Jahrhundert, Wien-KölnWeimar: Böhlau.

Landesmann, P. (1997), Rabbiner Aus Wien: Ihre Ausbildung, Ihre Religiösen Und Nationalen Konflikte, Vienna.

Mahler, R. (1958), Yidn in amolin Poyln: in likh fun tsifern: di demografishe un sotsyal-ekonomishe struktur fun Yidn: in royn-Poyln in XVIII yorhundert, Warsaw.

Margoshes, J. (2008), A World Apart. A Memoir of Jewish Life in Nineteenth Century Galicia, Boston: Academic Studies Press. 
Melamed, V. (1994), Evrei vo Lvove v XIII - pervaia polovina XX veka [Jews in Lviv from the $13^{\text {th }}$ to the first half of the $20^{\text {th }}$ century], Lviv.

Rozenblit, M. (2001), Reconstructing a National Identity. The Jews of Habsburg Austria during Word War I, New York: Oxford University Press.

Salmon, Y. (1998), Zionism and Anti-Zionism in traditional Judaism in Eastern Europe, in: S. Almog, J. Reinharz, A. Shapira (eds.), Zionism and Religion, Hanover-London: Brandeis University Press: $25-44$.

Shanes, J. (2012), Diaspora Nationalism and Jewish Identity in Habsburg Galicia, New York: Cambridge University Press.

Wurm, D. (1935), Z dziejów Żydostwa Brodskiego. Za czasów dawnej Rzeczypospolitej polskiej (do r. 1772), Brody.

\section{Internet sources}

Menda-Levy, O. (2010), Schorr, Yehoshu'a Heshel, YIVO Encyclopedia of Jews in Eastern Europe, http://www.yivoencyclopedia.org/article.aspx/Schorr_Yehoshua_Heshel [accessed 22 September 2017].

Statistical data on the population of Horodenka, "Horodenka, Ukraine", Jewishgen, http://data.jewishgen.org/wconnect/wc.dll?jg jgsys community -1039416 [accessed 18 August 2017].

Statistical data on the population of Kalush, "Kalush, Ukraine", Jewishgen, http://data.jewishgen.org/ wconnect/wc.dll?jg jgsys $\sim$ community -1040700 [accessed 18 August 2017]. 